\title{
ST
}

Science \& Technology

PAPER - OPEN ACCESS

\section{Inovasi Problem Based Learning dengan Strategi Pembelajaran Genius Learning Menggunakan Media Peta Konsep}

\author{
Author : : Arfiena Berutu dkk., \\ DOI $\quad: 10.32734 /$ st.v2i1.355 \\ Electronic ISSN $\quad: 2654-7082$ \\ Print ISSN : :2654-7074
}

Volume 2 Issue 1 - 2018 TALENTA Conference Series: Science \& Technology (ST)

This work is licensed under a Creative Commons Attribution-NoDerivatives 4.0 International License.

Published under licence by TALENTA Publisher, Universitas Sumatera Utara

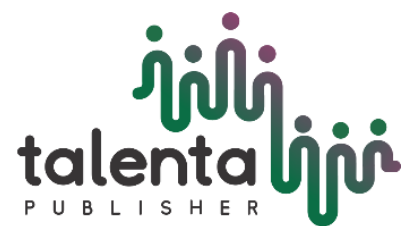


 \\ Inovasi Problem Based Learning dengan Strategi Pembelajaran Genius Learning Menggunakan Media Peta Konsep
}

\author{
Arfiena Fitria Berutu* ${ }^{\mathrm{a} *}$, Ani Sutiani ${ }^{\mathrm{b}}$, Angeline Viska Ayurosalia $^{\mathrm{c}}$, Febiana Wulandari $^{\mathrm{d}}$ \\ a,c,dProgram Studi Pendidikan Kimia, Pascasarjana, Universitas Negeri Medan, Medan \\ ${ }^{b}$ Jurusan Kimia, Fakultas MIPA, Universitas Negeri Medan, Medan \\ *berutuarfiena@gmail.com
}

\begin{abstract}
Abstrak
Penelitian ini bertujuan untuk mengetahui perbedaan hasil belajar kimia, yang dibelajarkan menggunakan strategi pembelajaran Genius Learning dengan model pembelajaran PBL (problem based learning) pada pokok bahasan reaksi redoks. Populasi dalam penelitian ini adalah seluruh siswa kelas X SMA Dharma Pancasila Medan. Pengambilan sampel dilakukan secara purposif untuk mengambil kelas eksperimen I dan eksperimen II. kelas pertama sebagai Kelas eksperimen 1 yang diajarkan dengan menggunakan Genius Learning Strategi dengan model pembelajaran PBL, sementara kelas kedua sebagai kelas eksperimen 2 belajar menggunakan model pembelajaran PBL . Untuk mengukur kemampuan siswa digunakan metode tes hasil belajar yang disusun dalam bentuk tes objektif dengan jumlah soal sebanyak 20 soal yang telah dianalisis dan memenuhi syarat validitas isi. Sedangkan untuk mengukur kemampuan. Begitu ditarik kesimpulan ada perbedaan yang signifikan antara hasil belajar siswa yang dibelajarkan dengan menggunakan strategi pembelajaran jenius belajar dengan model pembelajaran PBL.
\end{abstract}

Kata Kunci: Problem Based Learning, Genius Learning, Media Peta Konsep

\section{Pendahuluan}

Keberhasilan pembelajaran dipengaruhi oleh banyak faktor, baik faktor internal dari dalam diri siswa, maupun faktor eksternal yang berasal dari luar siswa. Sebagai salah satu faktor yang mempengaruhi belajar, minat adalah kecenderungan seseorang terhadap objek atau suatu kegiatan yang digemari yang disertai dengan perasaan senang, adanya perhatian dan keaktifan berbuat. Minat besar pengaruhnya terhadap hasil belajar siswa, bila bahan pelajaran yang dipelajari tidak sesuai dengan minat siswa, maka siswa tidak akan belajar dengan sebaik-baiknya karena tidak ada daya tarik baginya. Siswa yang tidak berminat terhadap suatu pelajaran tidak mempunyai perhatian terhadap apa yang diajarkan guru, siswa menjadi acuh, tidak mendengarkan penjelasan guru, bahkan rebut sendiri.

Selain faktor minat, motivasi juga berpengaruh terhadap keberhasilan belajar siswa. Motivasi merupakan suatu perubahan yang terdapat dalam diri seseorang untuk melakukan sesuatu guna mencapai tujuan. Tujuan yang hendak dicapai siswa ini merupakan pendorong atau penyemangat bagi siswa untuk lebih giat belajar. Dengan motivasi ini, siswa menjadi tekun dalam proses belajar mengajar, dan dengan motivasi pula kualitas hasil belajar siswa dapat diwujudkan dengan baik. Siswa yang mempunyai motivasi kuat dan jelas akan tekun dalam proses belajar mengajar dan akan berhasil dalam belajarnya.

Menurut Arends dalam Trianto [1] model problem based learning adalah model pembelajaran dengan fokus pemecahan masalah yang nyata, proses dimana peserta didik melaksanakan kerja kelompok, umpan balik, diskusi, yang dapat berfungsi sebagai batu loncatan untuk investigasi dan penyelidikan dan laporan akhir. Dengan demikian peserta didik didorong untuk lebih aktif terlibat dalam materi pelajaran dan mengembangkan keterampilan berpikir kritis. Penguasaan materi secara bermakna oleh siswa yang dilakukan dengan menampilkan materi ajar dalam bentuk masalah dapat mendorong dan melatih siswa untuk berpikir secara ilmiah.

Usaha lain untuk meningkatkan hasil belajar siswa selain menggunakan model pembelajaran yang tepat juga dapat dilakukan dengan memadukan strategi belajar dengan model pembelajaran yang tepat dan efektif, misalnya 
dengan menggunakan strategi pembelajaran Genius Learning. Genius Learning membantu anak didik untuk bisa mengembangkan kelebihan mereka sesuai dengan gaya belajar masing-masing karena proses pembelajaran yang terbaik yang dapat diberikan kepada para siswa adalah suatu proses yang diawali dengan menggali dan mengerti kebutuhan anak didik. Tujuan pembelajaran dengan strategi pembelajaran Genius Learning pada intinya adalah bagaimana membuat proses pembelajaran menjadi efektif, efisien, dan menyenangkan. Strategi pembelajaran Genius Learning dalam penerapan dan hasilnya diharapkan dapat membantu siswa untuk bisa mengerti kekuatan serta kelebihan potensi yang mereka miliki yang dapat dikembangkan.

Berdasarkan pengalaman pada saat observasi yang dilaksanakan disekolah SMA Dharma Pancasila Medan maka perlu diterapkan suatu strategi belajar yang dipadukan dengan model pembelajaran kimia yang mengajak siswa untuk aktif dalam proses pembelajaran. Penerapan strategi belajar Genius Learning dengan model pembelajaran Problem Based Learning (PBL) dapat dijadikan model alternative yang diharapkan dapat mengaktifan siswa dalam proses belajar mengajar. Dalam arti siswa harus aktif, siswa dapat mengerjakan soal-soal secara sturktur (dari tingkat yang rendah sampai tingkat yang rumit) dengan baik, saling berinteraksi dengan temantemannya, saling tukar informasi, dan memecahkan masalah. Sehingga siswa tidak ada yang pasif dalam menyelesaikan masalah pelajaran, yang ada adalah untuk menuntaskan materi belajarnya. Selain itu dengan menggunakan model pembelajaran PBL dapat menanamkan karakter siswa untuk berpikir kritis, bertanggung jawab, dan dapat berinteraksi dengan baik dengan sesama.

Selanjutnya Konsep-konsep Kimia dapat disampaikan kepada para peserta didik melalui medel dan strategi yang tepat, namun diperlukan juga suatu media pembelajaran yang sesuai agar semua konsep dapat disampaikan dengan baik. Menurut Hamalik [2], pemakaian media pembelajaran dalam proses belajar mengajar dapat membangkitkan keinginan dan minat yang baru, membangkitkan motivasi dan rangsangan kegiatan belajar, dan bahkan membawa pengaruh- pengaruh psikologis terhadap siswa. Proses belajar mengajar dengan bantuan media pembelajaran akan terasa menarik bagi siswa dan dapat membangkitkan motivasi dan minat siswa, serta dapat membantu siswa meningkatkan pemahaman, menyajikan data dengan menarik dan terpercaya, memudahkan penafsiran data, dan memadatkan informasi.Media yang dapat digunakan adalah peta konsep karena menunjukkan konsep ilmu yang sistematis dan struktur dibentuk mulai dari inti permasalahan sampai pada bagian yang mempunyai hubungan satu sama lain sehingga mempermudah pemahaman suatu topik. Peneliti sebelumnya menyatakan bahwa denganmedia peta konsep dapat meningkatkan hasil belajar siswa sebesar $14,03 \%$.

Hasil penelitian dengan menerapkan strategi Genius Learning telah dilakukan oleh beberapa peneliti terdahulu, diantaranya hasil penelitian yang dilakukan oleh Indah [3] dengan penerapan genius learning strategi untuk meningkatkan keterampilan menulis puisi bebas di Surabaya diperoleh hasil belajar yang sangat baik dimana nilai ketercapaian aktivitas guru mencapai 60\%. Penelitian juga dilakukan oleh Hozali [4] terhadap siswa di SMK N 3 Surabaya. Hasil penelitian yang didapat adalah perhitungan keseluruhan aktivitas siswa sebesar 82,375\% sehingga dikategorikan sangat baik. Penelitian ini menerapkan genius learning berbasis multiple intelligences yang memungkinkan siswa dengan kecerdasan berbeda dapat memaksimalkan kemampuan mereka masing-masing.

Penelitian ini bertujuan untuk Untuk mengetahui perbedaan hasil belajar kimia siswa yang dibelajarkan dengan Model Problem Based Learning denganStrategi pembelajaran Genius learningmenggunakan media peta konsep dibandingkan hasil belajar kimia siswa yang dibelajarkan dengan model problem based learningmenggunakan media peta konsep pada pokok bahasan reaksi redoks

\section{Metode}

Populasi dan Sampel. Populasi dalam penelitian ini adalah seluruh siswa kelas X SMA Dharma Pancasila Medan Tahun Ajar 2014/2015 yang berjumlah 200 siswa terdiri dari 5 kelas masing masing kelas berjumlah \pm 40 siswa. Pengambilan sampel dilakukan secara purposif untuk mengambil kelas eksperimen I dan eksperimen II. Hal yang menjadi pertimbangan adalah roster kedua kelas untuk mata pelajaran kimia berbeda tetapi guru yang mengajar sama.

Dalam melakukan penelitian ini, sampel dikelompokkan menjadi dua kelompok yaitu kelompok satu sebagai kelas eksperimen 1 yang diberi pengajaran menggunakan Model Pembelajaran Problem Based Learning yang dipadukan dengan Strategi pembelajaran Genius Learning dan kelompok kedua sebagai kelas eksperimen 2 yang menggunakan model pembelajaran Problem Based Learning. Berdasarkan permasalahan yang diteliti dan tujuan penelitian maka jenis penelitian merupakan penelitian eksperimen.. Rancangan penelitian menggunakan desain,yaitu seperti pada tabel 1. 
Tabel 1. Rancangan Penelitian

\begin{tabular}{cccc}
\hline Kelompok & Tes Awal & Perlakuan & Tes Akhir \\
\hline Eksperimen I & $\mathrm{T}_{1}$ & $\mathrm{X}$ & $\mathrm{T}_{3}$ \\
\hline Eksperimen II & $\mathrm{T}_{2}$ & $\mathrm{Y}$ & $\mathrm{T}_{4}$ \\
\hline
\end{tabular}

Keterangan :

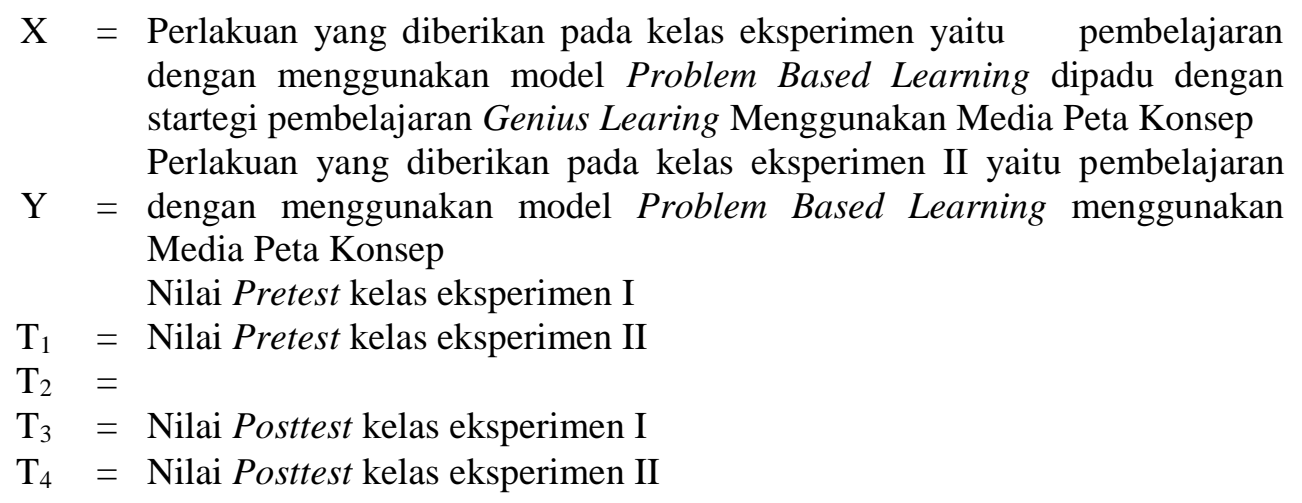

Dalam penelitian ini data yang diolah adalah hasil belajar siswa kedua kelas. Teknik analisis data yang digunakan adalah analisis dengan menggunakan rumus Uji-t.

\section{Hasil dan Pembahasan}

Data yang terdapat dalam penelitian ini diperoleh dari pretest yang diujikan sebelum dilakukan proses pembelajaran pada kedua kelompok sampel (kelas eksperimen I dan kelas eksperimen II) dan postest yang diujikan setelah dilakukan proses pembelajaran menggunakan Genius Learning Strategy dengan model pembelajaran Problem Based Learning pada kelas eksperimen I dan model pembelajaran Problem Based Learning pada kelas eksperimen II. Perolehan nilai rata-rata pretest pada kelas eksperimen I adalah 36,05 dan nilai rata-rata postest adalah 85,39 sedangkan nilai rata-rata pretest untuk kelas eksperimen II adalah 32.36 dan nilai rata-rata postest adalah 75,55 .

Tabel 2. Rata-rata, Standar Deviasi, dan Varians Data Pre-Tes

\begin{tabular}{ccccccc}
\hline & \multicolumn{2}{c}{ Nilai Rata - Rata } & \multicolumn{2}{c}{ Standar Deviasi } & \multicolumn{2}{c}{ Varians } \\
\cline { 2 - 7 } Kelas & Pretest & Postest & Pretest & Postest & Pretest & Postest \\
\hline Eksperimen I & 36,05 & 85,39 & 8,71 & 10,03 & 75,88 & 100,51 \\
& & & & & & \\
Eksperimen II & 32,36 & 75,55 & 9,57 & 6,37 & 91,53 & 40,68 \\
\hline
\end{tabular}




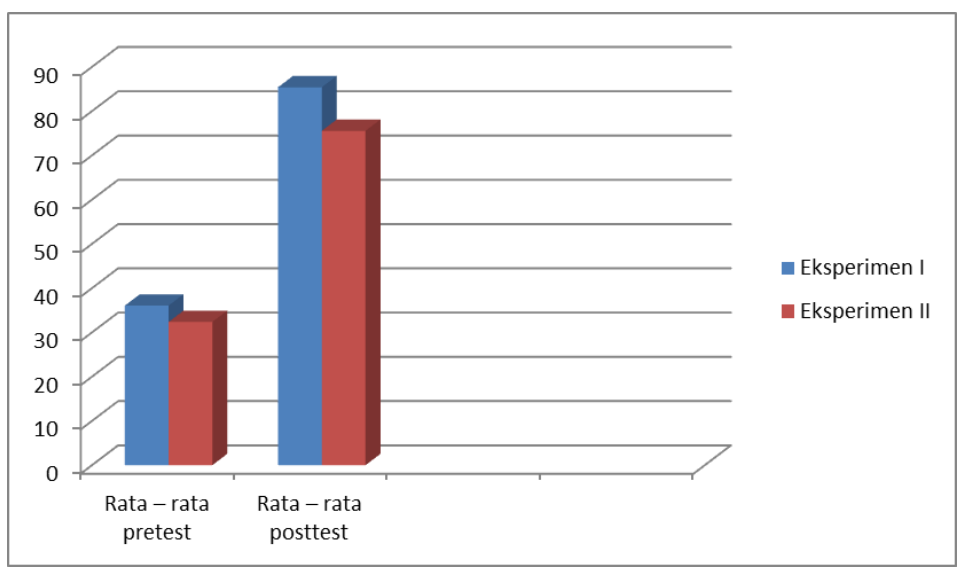

Gambar 1. Hasil Belajar Siswa.

Dari analisis data hasil belajar dalam penelitian ini pada kelas eksperimen I yang dibelajarkan menggunakan strategi pembelajaran Genius Learning dengan model pembelajaran Problem Based Learning sebelum diberikan perlakuan diperoleh bahwa nilai rata-rata hasil belajar siswa adalah sebesar 36,05 dan setelah dibelajarkan menggunakan strategi pembelajaran Genius Learning dengan model pembelajaran Problem Based Learning diperoleh nilai rata-rata hasil belajar siswa sebesar 85,39. Pada kelas eksperimen II yang dibelajarkan menggunakan model pembelajaran Problem Based Learning, sebelum diberikan perlakuan diperoleh bahwa nilai rata-rata hasil belajar siswa adalah sebesar 32,36 dan setelah diberlajarkan menggunakan model pembeljaran Problem Based Learning diperoleh nilai rata-rata hasil belajar siswa sebesar 73,55. Hal ini konsiten dengan penelitian Magda [5] menunjukkan bahwa prestasi belajar siswa yang dibelajarkan strategi pembelajaran Genius Learning memberikan prestasi belajar matematika yang lebih tinggi. Selain dengan menggunakan strategi pembelajaran Genius Learning, dalam penelitian ini juga digunakan model pembelajaran Problem Based Learning yang mendorong kemampuan kerjasama sehingga membuat peningkatan hasil belajar yang lebih signifikan, sesuai dengan penelitian sebelumnya yang dilakukan oleh Fitrah [6] membuktikan bahwa pembelajaran berbasis masalah dengan media MS Frontpage memberikan perbedaan hasil belajar lebih tinggi 14\% dibandingkan siswa yang diajarkan secara konvensional.

\section{Kesimpulan}

perbedaan hasil belajar kimia yang signifikan antara siswa yang dibelajarkan menggunakan strategi pembelajaran Genius Learning dengan model pembelajaran Problem Based Learning dan hasil belajar kimia siswa yang dibelajarkan menggunakan model pembelajaran Problem Based Learning adalah sebesar 11.84 pada pokok bahasan reaksi reduksi dan oksidasi

\section{Referensi}

[1] Trianto., (2011), Model-Model Pembelajaran Inovatif Berorientasi Konstruktik, Penerbit Prestasi Pustaka, Jakarta.

[2] Hamalik, O., (2001), Perencanaan Pengajaran berdasarkan Pendekatan Sistem, Penerbit Bumi Aksara, Bandung

[3] Indah, M., (2012), Penerapan Genius Learning Strategy untuk meningkatkan keterampilan Menulis Puisi Bebas Siswa Kelas V SDN Surabaya, Jurnal Penelitian, Universitas Negeri Surabaya, Surabaya

[4] Hozali, I., (2012), Pengaruh Penerapan Strategi Genius Learning Berbasis Multiple Intelligences Terhadap Hasil Belajar Siswa Pada Standar Kompetensi Memahami Sifat Dasar Sinyal Audio di SMK, Jurnal Penelitian, Universitas Negeri Surabaya, Surabaya.

[5] Simanjuntak, Magda Dwi., (2014), Pengaruh Penggunaan Strategi Pembelajaran Geniuslearning Dengan Model Pembelajaran Problem Based Learning Terhadap Hasil Belajar Kimia, Berpikir Kritis Dan Kerjasama Siswa Sma Pada Pokok Bahasan Reaksi Redoks., Skripsi, Unimed, Medan

[6] Fitrah, A., (2013), Pengaruh Strategi Pembelajaran Berbasis Masalah Dengan Media MS Frontpage Terhadap Kreativitas Dan Hasil Belajar Siswa SMA Pada Materi Larutan Elektrolit Dan Non Elektrolit., Tesis, Unimed, Medan 